Tatiana Bubnova

\title{
Signo poético e identidad rusa en el cine de Tarkovski
}

No quieren sacrificio los vacíos cielos:

son más seguros el trabajo y la constancia. ${ }^{1}$

Osip Mandelstam

El arte es un metalenguaje a través del cual los hombres han de comunicarse entre sí, conocerse y asimilar sus experiencias. De ningún modo se trata de obtener un provecho práctico, sino de realizar la idea del amor, que no tiene sentido sino en el sacrificio.

Andrei Tarkovski

Ésta es una lectura de tres películas de Andrei Tarkovski - Andrei Rubliov (1969), El espejo (1974) y Nostalgia (1983)— como una secuencia evolutiva y una unidad del sentido. Sabemos que Tarkovski se pensaba a sí mismo como poeta del cine, y la poesía de múltiples maneras está relacionada con su obra. En la serie de películas que examino elegí el motivo de la conciencia ética del artista que surge en un ir y venir permanente entre la concepción de la Historia y la del individuo. El motivo (TB).

${ }^{1}$ Todas las traducciones de la poesía rusa incluidas en este trabajo son mías 
emerge en medio de un panorama —más simbólico y generalizador que realista - de la Historia nacional en Andrei Rubliov. ${ }^{2}$ En El espejo, el motivo de la Historia atraviesa mediante el recurso de la memoria el mundo interior, al interrogar a la subjetividad desde las primeras etapas de su despertar hasta un posicionamiento, otra vez dentro de la Historia. Finalmente, en Nostalgia se muestra la actuación de un yo ruso en la frontera con un universo cultural y nacional distinto, frontera vivenciada intensamente pero nunca rebasada. En las tres películas se trata de un individuo creador, un artista. Su comportamiento se observa ora desde una realidad nacional (de hecho, actual) vista como la fatalidad de su misma Historia, ora en su desarrollo estrictamente individual, aunque en un permanente contacto con los tiempos oscuros en los que le toca vivir, y los que también son parte de su formación, o bien en una confrontación con un mundo de lo no-propio: una cultura ajena aunque a la vez "propia", debido a los múltiples vínculos formativos, históricos y culturales que las unen.

Tarkovski es poeta del cine, no cabe duda; y si se concibe de esta manera a sí mismo, no se trata de una simple figura retórica sino de una posición ética, aunque también de la búsqueda de un lenguaje cinematográfico ${ }^{3}$ que pueda funcionar como una analogía adecuada entre la percepción de la palabra hablada — antes que escrita_ ${ }^{4}$ de la poesía y la instantaneidad

\footnotetext{
${ }^{2}$ La propia cita del Eclesiastés, epígrafe a Andrei Rubliov, ha de leerse como una interpelación al presente: "Lo que fue, será, y lo que se hacía, se hará, y no hay nada nuevo bajo el sol..."

${ }^{3}$ He aquí una profesión de fe de Tarkovski sobre el cine como construcción técnica: "Los problemas técnicos son juegos de niños; se puede aprender cualquiera de ellos. Pero el pensar con independencia y dignidad no es igual a aprender a hacer algo, como tampoco lo es tener una personalidad propia" (Tarkovski, Esculpir el tiempo, p. 126).

${ }^{4}$ Lo subrayo para adelantar la observación sobre la predominancia de la percepción oral en la poesía rusa, que se lee y se memoriza — hasta ahora— por los lectores en una medida incomparablemente mayor que la poesía en cualquier otra lengua contemporánea que yo conozca. Asimismo, los poetas muchas veces con-
} 
vivencial de la compleja y multidimensional imagen en la pantalla. ${ }^{5}$ De cualquier manera, la poesía en sí está presente en su obra de muchas maneras y forma parte indispensable de sus recursos fílmicos. Su propio padre fue poeta (Arseni Tarkovski, 1907-1989); además, su poesía es un elemento muy importante, profundamente relacionado con la imagen y el sonido en $\mathrm{El}$ espejo e incluso en Nostalgia (el protagonista de esta última película es significativamente también un poeta). Pero para comprender el peso del concepto poesía en Tarkovski, hay que señalar que lo importante no es lo temático, sino el papel que la poesía ocupaba - tal vez todavía ocupe — en la formación de la intelligentsia rusa del siglo $\mathrm{xx}$, y muy especialmente en los años cincuenta y sesenta, décadas en que Tarkovski se forma y surge como creador. Como muchas veces se ha explicado, tradicionalmente en Rusia, y luego en la Unión Soviética, la literatura se convirtió, a falta de un instrumento idóneo en la vida social y política, en un espacio para expresar posturas ideológicas más allá de lo estético. Con esto no pretendo decir, desde luego, que el cine de Tarkovski se encuentre politizado o ideologizado en el peor sentido de la palabra; no obstante, este cine no carece de la ideología que el mismo arte y en particular la literatura implican. Ahora bien, la poesía es sobre todo la medida de lo ético por su peculiar visión estética de la vida y del acto.

ciben la línea versal desde el sonido, no desde la página en blanco (esto es válido en primer lugar para Mandelstam, del que hablaré especialmente); desde luego, no pretendo afirmar que esto sea una verdad universal, pero se trata sin embargo de una tendencia viva.

\footnotetext{
${ }^{5}$ Las películas de Tarkovski se adaptan mal a la pantalla televisiva: la epicidad de Andrei Rubliov está relacionada con la amplitud de la wide screen. Cuando en las secuencias finales la famosa Trinidad del Antiguo Testamento de Rubliov, su obra más célebre, que mide al natural 142 por $114 \mathrm{~cm}$, se extiende hasta las dimensiones de la pantalla ancha, se trata sin lugar a dudas de un tropo visual que tiene un determinado efecto sobre el espectador. La levitación de la madre en $\mathrm{El}$ espejo pierde todo su carácter extraordinario al ser reducida a las 20 pulgadas de pantalla de un televisor promedio; la monumentalidad italiana de Nostalgia asimismo no puede leerse adecuadamente en reducción.
} 
¿Cuál fue la poesía que aparentemente influyó en Tarkovski? La poesía clásica rusa, principalmente del siglo XIX ${ }^{6}$ (también de algunos poetas del XVIII, como Derzhavin), pero sobre todo la de aquellas generaciones de principios del siglo xx que desaparecieron del panorama de la cultura oficial soviética después del gran parteaguas epocal de 1917: los simbolistas - Blok, Briusov, Biely; y los postsimbolistas, muchos de ellos emigrados- muy especialmente, Pasternak, Ajmátova, Mandelstam y Tsvetáieva, los dos primeros semiprohibidos o marginados permanentemente por el régimen, los dos segundos apenas redescubiertos en aquella época por haber sido perseguidos y sólo leídos en parte durante el "deshielo" provisional que trajeron los cambios políticos ocurridos después de 1956 (XX congreso del PCUS). ${ }^{7}$ Hay otros nombres siempre presentes para las generaciones intermedias de los intelectuales soviéticos (nacidos en la víspera o inmediatamente después de la Revolución); de hecho, todos ellos formaban el clima intelectual y emocional de la disidencia que prepararía los radicales cambios de los años ochenta.

Había por cierto muchos versos prohibidos; aunque por supuesto en los sesenta ya no se daban casos tan flagrantes como los de muchos poetas que perecieron en los campos de concentración durante la década de los treinta (Mandelstam entre ellos); no obstante, no pocos terminaron siendo deportados o incluso recluidos en los campos durante los años sesenta y aún después (Brodsky es un buen ejemplo, pero también varios escritores menos conocidos en Latinoamérica como Siniavski

\footnotetext{
${ }^{6}$ Pushkin y Lérmontov, desde luego; Tiutchev, Boratynski, para mencionar a algunos de los que menos se conocen fuera de su país. Por supuesto, aquí sólo doy una lista rudimentaria por no abrumar al lector con un gran número de nombres desconocidos e impronunciables.

7 Para caracterizar el ambiente hay que agregar que se leía también a Maiakovski (1895-1930) y a Esenin (1895-1925), dos poetas diametralmente opuestos; aunque en la obra de Tarkovski no encuentro huella de la influencia explícita de estos escritores, al menos no del primero.
} 
— prosista— y Daniel — poeta—). La poesía como oficio seguía siendo un asunto peligroso ${ }^{8}$ si uno se permitía hablar en un lenguaje propio, no prescrito. Prevalecía la idea romántica de realizar una edificación estética de la propia vida, buscando darle significado mediante actos entre los cuales la poesía tuvo un lugar especial, un significado legible a partir de la totalidad de una vida que podía influir a su vez en los demás. Desde este punto de vista la muerte se interpreta como el desenlace que da sentido a toda una vida. "La muerte de un artista no debe ser excluida de la cadena de sus logros creativos, sino vista como su eslabón último y conclusivo... [La muerte] no sólo es notable en cuanto un crecimiento póstumo fabuloso del artista a los ojos de la masa, sino que parece funcionar como fuente de su creación, su causa teleológica” (Mandelstam, vol. 2, p. 157).

Entre las generaciones soviéticas de poetas, Esenin se suicidó ${ }^{9}$ Maiakovski y Tsvetáieva, también. Mandelstam murió en un campo de concentración en el Lejano Oriente soviético. La biografía de Ajmátova es la de testigo y participante de un destino común: ${ }^{10}$ su primer marido y también poeta N. Gumiliov fue fusilado en 1921; su hijo Lev pasó la vida entera en los campos, lo mismo que su segundo marido, el teórico de arte N. Punin ${ }^{11}$ (aquí me limito estrictamente a los nombres mencionados en mi texto). ${ }^{12}$

\footnotetext{
8 Tanto social como simbólicamente; es por eso que Tarkovski hace suya la posición de Pasternak: "La creación artística exige del artista que 'muera completamente' en el sentido más amplio de estas palabras" (Tarkovski, Esculpir el tiempo, p. 42). Pasternak también había dicho: "Las líneas de sangre matan:/ Afluyen por la garganta para matarte". Nótese la asociación indisoluble de la voz ("garganta") con la escritura ("líneas").

${ }^{9} \mathrm{Si}$ es que no fue asesinado, como se sospecha ahora.

${ }^{10}$ En palabras de Mandelstam, "con el montón y el rebaño”.

${ }^{11}$ En los años sesenta, al enterarse de que Brodsky fue deportado, Ajmátova, su guía espiritual, dijo: "¿Qué biografía le están construyendo a nuestro pelirrojo!”

12 Pushkin fue deportado varias veces y murió en un duelo provocado para eliminarlo; Lérmontov fue deportado al Cáucaso y destinado a morir en un comba-
} 
La vida y la muerte de un poeta tienen un significado especial, una teleología; ya en los tiempos soviéticos, y transformada en un mesianismo socialista, esta idea resurge en Nikolai Ostrovski (autor de Así se forjó el acero): "Lo más preciado del ser humano es la vida, que se le da sólo una vez, y hay que vivirla de tal manera que después no se tengan que lamentar los años vividos sin propósito, para que no queme la vergüenza por un pasado ruin y mezquino..." Por los versos se podía vivir y morir (a veces por el solo hecho de leer los ajenos), pero la recompensa se consideraba suprahistórica y supraindividual, de modo que valía la pena. Desde luego era parte de un imaginario colectivo que contribuía al prestigio moral de la poesía, más que una práctica sostenida. Recuerdo la anécdota que contaba uno de los poetas rusos, según la cual un poeta occidental había dicho: cualquiera de "nuestros" poetas (léase occidentales) se cambiaría con gusto de lugar por uno de los "vuestros" (soviéticos, pero de aquellos que vivían al borde del peligro). Se sobreentendía que el motivo era lo mucho que la poesía significaba para la gente en Rusia. En efecto había una gran cantidad de poetas, privaba una alta cultura de versificación y los libros de poesía, incluso de autores contemporáneos, así como las traducciones, se vendían al instante en tirajes monumentales.

El discurso social ${ }^{13}$ en la época de maduración de Tarkovski, y en particular el de la disidencia, estaba permeado por líneas versales aforísticas, o bien por estrofas y poemas enteros, in-

te, como militar que era, a no ser que cayera igual que Pushkin en un duelo. Venevitinov, Polezhaiev, Dostoievski, Herzen son otros creadores ilustres que sufrieron persecuciones políticas.

${ }^{13}$ Entiendo por discurso social "el vasto rumor fragmentado que figura, comenta, conjetura, antagoniza el mundo" (Robin y Angenot, en Malcuzynski, Sociocríticas..., p. 52). Dicho de otra manera, "el discurso social se define como el conjunto regulado por las convenciones y tomado en sus configuraciones ideológicas, de lo que se dice y se escribe en un estado de la sociedad" (Malcuzynski, op. cit., p. 22). 
cluso tan largos como el Poema sin héroe de Ajmátova, que jamás se publicó en vida de su autora. Junto a los poetas de ayer y hoy se leían escritores olvidados y semiolvidados en cuyas páginas se encontraban soluciones para el futuro mediante ideas impronunciables para la ideología soviética, aunque fueran inherentes a la tendencia mesiánica de los llamados eslavófilos, ${ }^{14}$ siempre presente en la cultura rusa. La tendencia occidentalista, más explícitamente afín a la ideología oficial, y representada por figuras de prestigio tan reconocido como Turgueniev (1818-1883) y Herzen (1812-1870), podía abarcar también el mesianismo marxista, de ideas bastante contrarias. Chaadáiev, figura presente en el horizonte de Tarkovski (ver infra), es exponente de este occidentalismo pesimista, al lado del cual Pushkin, admirador del gran reformista Pedro I, parecería eslavófilo. Ésta es la lectura que en El espejo Tarkovski le da al debate entre Chaadáiev y Pushkin, omitiendo la opinión del primero. Dostoievski será otro gigante que a pesar de haber sido prácticamente marginado durante treinta años siempre se releerá junto con el mesianismo ortodoxo y la teoría de "tierra y suelo", aportando la idea de la conciencia individual y de la culpa de todos por todos (en un país imbuido por el perversamente cándido espíritu de un bien intencionado espionaje y de la delación política legitimada y cultivada con celo por la ideología oficial). Así, a la luz de la autocrítica parcial del Partido y del regreso masivo de los sobrevivientes de los campos, la época estalinista va siendo repensada, reevaluada y puesta en una perspectiva crítica, que treinta años después —en

\footnotetext{
${ }^{14}$ La eslavofilia fue un importante movimiento intelectual que comenzó en Rusia en la década de 1830 y pasó por diversos períodos de desarrollo, extinción y resurgimiento hasta la época contemporánea. Se trata de un esfuerzo sostenido para definir la identidad rusa a partir de las formas culturales nacionales extraídas de un remoto pasado preindustrial. Los orígenes históricos de la eslavofilia pueden verse como reacción de las clases privilegiadas de Rusia a la experiencia de la occidentalización (sobre todo la iniciada en la época de Pedro I, a principios del siglo XVIII).
} 
la década de los ochenta - alimentaría el caldo de cultivo ideológico de la perestroika.

El poeta inédito Iosif Brodsky (1940-1996), quien posteriormente sería premio Nobel, fue expulsado del país en 1972 bajo la condena de cosmopolitismo, apoliticidad y parasitismo social. ${ }^{15}$

Las líneas versales - al lado del chiste político-erótico y de las declaraciones y manifestaciones de los disidentes, que cuestan la vida y/o la carrera a los que se atreven a producirlas o repetirlas - vuelan en el aire sustentando un clima ideológico donde la poesía sería un recurso de expresión privilegiado y por antonomasia pleno de prestigio ético. Éste era el ambiente en que Tarkovski tuvo la suerte de formarse como creador. Es por eso que su vocación tenía que definirse justamente como poética (no filosófica o, por ejemplo, puramente estética). Ser poeta es tener derecho propio a un juicio ético que vale para los demás. "La poesía no es sino la conciencia de tener razón", había dicho el poeta Osip Mandelstam. "En Rusia, un poeta es más que poeta...", le hace tímido eco un poeta soviético que nunca se arriesga demasiado, pero al que evidentemente le duele la conciencia.

Hay que destacar la importancia que Andrei Tarkovski como cineasta le atribuye a la palabra, y particularmente a la palabra poética. No se refiere sólo a la palabra esteticista, sino a aquella que es capaz de provocar un conflicto y de dar cuenta cabal de una ruptura real, vinculada a una vida que puede acabar en la muerte "no natural", para decirlo de una manera no demasiado escandalosa. En efecto, Tarkovski, niño prodigio de la cinematografía soviética pero también conciencia doliente compartida por muchos que prefirieron para sí un desti-

\footnotetext{
15 Pronto le seguiría Alexandr Solzhenitsyn, quien prepara ya en la clandestinidad el reporte monumental sobre el famoso archipiélago de la GULAG (Dirección Estatal de los Campos).
} 
no menos complicado, vivió en el borde, sin compromisos (lujo que pudo permitirse gracias a cierta contingencia histórica, pero también — según diría el materialismo histórico- por la suerte de haber nacido cuando estaban dadas las condiciones para que fuese oído), e hizo justamente lo que quiso hacer, sin concesiones de ninguna clase. Su exilio semivoluntario, su éxito mundial y su muerte por enfermedad se leen en este contexto como una vida ofrecida en sacrificio, es decir, la Vida de un poeta...

Tarkovski había dicho que no creía en la muerte; en sus palabras hay un eco de las líneas de Anna Ajmátova: "No hay muerte: todos lo saben,/ y se ha vuelto lugar común./ Que me cuenten qué es lo que hay". 16

Para no perder el hilo, debo empezar in medias res analizando El espejo, para luego volver a Andrei Rubliov.

El espejo lleva una especie de epígrafe filmado. Empieza, sin previo aviso, cuando un niño (al que sólo mucho después podremos identificar como Ignat, hijo del protagonista) prende el televisor: Se está transmitiendo un programa documental grabado en el consultorio de una doctora logoterapeuta. Un adolescente tartamudo, que casi no puede articular palabra, se somete a una terapia por hipnosis. Hablar es comunicarse, expresar a sí mismo y en cierta forma dar vida a la propia experiencia. Esta persona que apenas puede decir nada pues se encuentra afectada en sus capacidades articulatorias y comunicativas, de pronto se atreve a decir clara y limpiamente, "sin miedo a su propia habla y a su voz" (en palabras de la logoterapeuta), —con lo cual

\footnotetext{
${ }^{16}$ El motivo se puede encontrar también en un poema leído, por cierto, en $\mathrm{El}$ espejo:

No creo en los presentimientos,

no le temo a la mala suerte. No rehuyo

la calumnia ni el veneno.

La muerte no existe.

Son inmortales todos y todo...
} 
queda curado de una vez y para siempre: "Yo puedo hablar". El mundo se abre con la palabra. De este modo arranca la película, vienen después los títulos, los créditos y finalmente la voz de Innokenti Smoktunovski, ${ }^{17}$ protagonista que empieza a narrar. Tal protagonista siempre será tan sólo una Voz. ${ }^{18}$

El argumento está íntimamente ligado a la capacidad narrativa, a su vez relacionada indisolublemente a la palabra poéti$c a$, porque la historia y las razones de la Voz cobran sustento en los versos de Arseni Tarkovski (que él mismo lee), sin los cuales el aspecto visual, el montaje y la música no son capaces de adquirir la plenitud y multidimensionalidad de sentido que la poesía les confiere. En algunas ocasiones la propia palabra poética nos ofrece además la interpretación axiológica de un motivo histórico que sin ella se perdería o parecería ambivalente, enigmático. Así, en los recuerdos iniciales, la pasada felicidad de los padres sólo se adivina en su etapa de declinación (están a punto de separarse), mientras se recita un poema que habla de la gloria del amor. El toque histórico se logra vinculando la secuencia posterior (todo el episodio de la Madre en la editorial e imprenta del Estado) con la estrofa final del poema amoroso. ¿Cuándo sucedía todo aquello? La Voz nos responde: "Cuando el Destino seguía nuestros pasos/ como un demente con la navaja en mano". Lo que sucede en la editorial puede fácilmente llevar a la Madre a un "destino final": una errata obscena en las obras completas de Stalin pudo haber terminado de una manera siniestra, no sólo para ella sino para cuantos estuviesen involucrados en el proceso. Es por eso que todos los que rodean a la Madre en la imprenta están no sólo nervio-

17 Gran actor ruso, titular de un inolvidable Hamlet (1964) de G. Kózintzev, por desgracia totalmente desconocido, al parecer, fuera de su país.

${ }^{18}$ El protagonista, Alexei, está a punto de morir, como nos enteramos hacia el final. Su enfermedad está relacionada, sintomáticamente, con la voz: le duele la garganta; se trata sólo de un mal de las anginas pero la dolencia deriva en algo fatal. Al final, el doctor dice que a Alexei le duele la conciencia... 
sos sino mortalmente preocupados. Cuando la tensión desaparece, la amiga de la Madre, Lisa, recita para sí misma una paráfrasis basada en el inicio de la Divina Comedia, acerca de la mitad del camino de la vida...

Habiendo establecido así la primacía de la Palabra y de la Voz en cuanto autoridad ética dentro de la obra de Tarkovski, volvamos al principio: Andrei Rubliov. En apariencia se trata de una película histórica pero de hecho no lo es. El historicismo acartonado, el etnologismo y la ingenua fidelidad a los "hechos" no estaban entre los propósitos de Tarkovski, como bien explica en Esculpir el tiempo. Los rasgos "históricos" aparecen sumamente estilizados, y el anacronismo (desde luego consciente) cobra valor de procedimiento retórico. La película trata de la vida de un pintor religioso que vivió a finales del siglo XIV y principios del xv, entre cuyas obras la más famosa es la Trinidad del Antiguo Testamento, pintura que "protagoniza" las últimas escenas de la obra. La biografía del pintor es en realidad totalmente desconocida; los datos de su vida a los que la película alude constituyen un guiño evidente a la época del espectador; ciertos episodios son una inserción retórica, absolutamente anacrónica pero con un potencial explicativo que pertenece al orden poético.

En mi opinión, las líneas versales del discurso social al que hice referencia antes se transforman aquí, sin manifestarse vocalmente ni por escrito, en una imagen filmada, sobre un fondo que selecciona algunas y omite otras. De esta forma se cambia el significado de las ausencias, legibles desde el contexto de la emisión/recepción original del discurso cinematográfico, y se establece un diálogo - o incluso una disputa - con un poeta no nombrado e incluso muerto treinta años antes de la aparición de la película. Esta discusión proseguirá en El espejo.

El poeta ausente es Osip Mandelstam, pocas veces mencionado por Tarkovski en sus escritos. Sin embargo, la poesía y la biografía de su padre, Arseni Tarkovski, están determinantemente vinculadas a este nombre. El cineasta no podía dejar de 
saberlo. Más aún, en el documental que le dedica un discípulo polaco, aparece Larisa Tarkovskaia leyendo líneas de Mandelstam transcritas en el diario de su marido: "El carácter hierático, es decir sagrado, de la poesía está condicionado por la convicción de que el ser humano es lo más sólido que existe" (Mandelstam, vol. 2, p. 186). Es claro que Tarkovski concebía su propia actitud hacia el arte de acuerdo con las palabras de Mandelstam, quien era su autor de cabecera, aun cuando sin duda no estuviera de acuerdo con todo lo que el poeta decía.

Para Mandelstam, judío de nacimiento, adquirir a plenitud la lengua rusa significó un gran esfuerzo, debido a las condiciones de su ambiente familiar. En la época de su formación como poeta, el lenguaje de la poesía había sido comparado con el balbuceo o tartamudeo "divino" (lo que nos remite al episodio inicial o "epígrafe" de El espejo, arriba mencionado). En medio de esta lucha por la lengua y en el contexto de las teorías acerca del lenguaje poético, Mandelstam hace algunas reflexiones originales sobre las cuestiones de identidad y de los destinos históricos de Rusia.

El argumento de la película Andrei Rubliov se desarrolla entre dos episodios clave que funcionan a modo de introducción y epílogo, sin relación con las peripecias de la vida del pintor. El primer episodio, El globo, está totalmente desvinculado del argumento salvo por su simbolismo; el último, intitulado $\mathrm{La}$ campana, y en apariencia independiente también, hace sin embargo de Rubliov el testigo de la historia protagonizada por un adolescente en el papel de niño prodigio.

En El Globo un inventor medieval se propone realizar un vuelo en un globo rudimentario para observar el mundo desde arriba. Al ser perseguido por los escandalizados creyentes emprende el vuelo, y aunque alcanza a echar un vistazo a la tierra desde las alturas, se estrella casi en seguida. ${ }^{19}$ Se trata pues de

\footnotetext{
${ }^{19}$ En mis oídos suena la canción "El vuelo interrumpido", popular en la época, del cantautor V. Vysotski, que también metaforiza una muerte de poeta: "Un
} 
un poeta, de un soñador que apuesta la vida para ver más allá de lo cotidiano y que está seguro de tener la razón; y en cierta forma la tiene, pues logra volar aun cuando la hazaña le cuesta la vida: parábola de una vida poética rusa. ${ }^{20}$

El siguiente episodio, El juglar, nos muestra a un grupo de monjes, también pintores, de viaje. Durante una tormenta toman un descanso en un cortijo campesino, donde todo un equipo de trabajadores espera que escampe. Un juglar aprovecha el descanso involuntario para dar una representación. Baila y canta versos obscenos sobre las autoridades. Alguien lo denuncia y de inmediato llega una especie de "policía política" medieval, lo golpea muy profesionalmente y se lo lleva. En el último episodio, La campana, nos enteramos de que el juglar pasó diez años en el calabozo donde le arrancaron la mitad de la lengua (apenas puede hablar); el juglar acusa a Rubliov de haberlo denunciado, aunque de hecho quien lo había delatado era otro monje, Kirill. La historia es más bien propia de los tiempos de Stalin, cuando a la gente la detenían por menos que eso (Mandelstam recitó de memoria, en la calle, un poema contra Stalin; una vez arrestado encontró el poema escrito en su expediente, sobre el escritorio de su instructor de oficio). En los tiempos de Kruschev (años cincuenta, época de los estudios profesionales de Tarkovski) muchos empezaron a regresar de los campos, y entre ellos hubo quienes fueron a visitar a sus delatores, provocándoles un infarto al verse cara a cara con aquellas víctimas de su denuncia que habían vuelto de la nada. Se narraban muchas historias de esta

caballo que cae en plena carrera, un pájaro, en pleno vuelo./ ¿De quién es la culpa?". Entre las imágenes visuales del episodio hay un caballo que cae; no obstante, me limito a una observación a pie de página, sin pretender establecer vínculos más sólidos que una libre asociación con la película.

${ }^{20}$ El episodio es absolutamente anacrónico desde el punto de vista de la Historia. Estos vuelos - y no en globo, sino con alas al estilo de Leonardo- se registran en Rusia apenas en el siglo XVIII. Tarkovski da cuenta de la intención simbólica del anacronismo en Esculpir el tiempo. 
clase; un ejemplo puede hallarse en las memorias de la viuda de Mandelstam — parte del "vasto rumor fragmentado" 21 de los tiempos post-estalinianos. En la película se trata de otro tipo de anacronismo, mediante el cual Tarkovski habla con $s u$ época y $s u$ gente, en vez de reconstruir una supuesta realidad "histórica" —atribuible más a la época de Iván el Terrible (unos ciento cincuenta años después de la muerte de Rubliov) que al período de la dispersión feudal y las guerras intestinas en que el pintor vivió.

Toda una serie de imágenes visuales mediante las cuales se hace discreta referencia a una supuesta realidad histórica permiten de nueva cuenta la asociación con las imágenes verbales de la poesía de Mandelstam. No se trata de la reconstrucción etnográfica de un ambiente histórico, sino de un guiño hacia el espectador para detectar el clima ético de una sociedad. La ciudad de Moscú en los tiempos del pintor Teófanes el Griego (en el episodio de la plaza de mercado - la Plaza Roja-, que es el lugar del cadalso) está caracterizada por lo que podríamos llamar la visualización de la metáfora poética de Mandelstam. En un poema, el poeta acosado está dispuesto a trasladarse a Siberia "para no ver al cobarde, ni la mugre pegajosa, ni los huesos sangrientos en la rueda", metáfora de una Moscú en tiempos de Stalin, y aun después, cuando la gente ocupada en asuntos de compraventa es por entero indiferente hacia quienes por defender $s u$ verdad sufren injustamente la tortura de la rueda.

El apocalipsis anunciado por Teófanes incluía, como si fuera una profecía, que todos los "pecadores" descargarían sus culpas sobre el prójimo, cosa que en efecto sucedió en Rusia después de la muerte de Tarkovski.

Otro ejemplo de contrapunto con las visiones poéticas de Mandelstam es el episodio de la toma de la catedral de Vladímir

${ }^{21}$ Cfr., supra, nota 13. 
por los tártaros (instigados por el Príncipe), y la muerte del tesorero, muy verosímil en términos históricos, cuando vierten alquitrán hirviente en su garganta - lo que hace recordar aquellas líneas de Mandelstam sobre la garganta del poeta tapada con estaño derretido.

El verdadero contrapunto al episodio del globo, que simboliza el sacrificio poético, viene a ser el pasaje de La campana, donde una obra (la campana, cuya fundición dirige un adolescente que se confiesa ignorante), asimismo realizada al azar y a tientas, llega a feliz término: ¡milagro del arte! Debemos entender que el protagonista de la hazaña metalúrgica, Borís, resulta ser el catalizador del retorno de Andrei Rubliov a su arte, quien lo había abandonado diez años atrás a causa de las tragedias de que fuera testigo, pues éstas habían devaluado ante sus ojos la labor creativa.

El episodio de la campana muestra toda la inconsistencia profesional del niño artesano, quien de hecho ignora el secreto de la fundición (lo confesará a Rubliov en privado al final del episodio, cuando la campana ya está hecha y suena). A pesar del éxito final debido al talento espontáneo y a la casualidad, el chico carece de reconocimiento y estatus de principio a fin, y aunque logra ganarse el respeto de sus ayudantes mayores en el proceso de fundición, permanece marginado y despreciado por la autoridad: su papel ha sido y será siempre instrumental para lograr los fines que el poder persigue. Lo peor es que Borís tampoco cree en sí mismo y considera casual y milagroso el hecho de que la campana suene; no está seguro de su conocimiento y capacidad. (Tocar las campanas, por cierto, es un arte tradicional ruso y posee un poder evocativo y emblemático en la definición de la identidad; ha renacido en las últimas épocas y representa parte de un ideario que recupera los valores eslavófilos).

Recordemos los sarcásticos comentarios "occidentalistas" del escritor A. I. Herzen a propósito de los dos "portentos" 
realizados por el talento ruso autóctono; se trata de dos reliquias históricas de los siglos XVI y XVII respectivamente, guardadas en el Kremlin de Moscú: la campana "rey" (kolokol en ruso es masculino), del tamaño de un edificio pero desgraciadamente rajada, y el cañón "rey", asimismo descomunal, que jamás fue disparado. Para Herzen éstos son símbolos de la autonomía cultural histórica rusa: una campana que jamás se tocó, y un cañón de adorno que nunca se disparó. ${ }^{22}$

Un par de comentarios poéticos viene a la mente, ambos de autores entrañables para Tarkovski: uno de Tiutchev (18011879) y otro de Mandelstam. La cuarteta de Tiutchev es emblemática para halagar la idea de la identidad rusa, pero paradójicamente viene como anillo al dedo para problematizar el episodio La campana. El elemento de milagro y de fe sustituye aquí a la racionalidad, supuestamente exclusiva de la mente "occidental". Dice el poeta:

No se puede entender a Rusia mediante la razón, no se la puede medir con una común medida.

Tiene un porte diferente:

sólo se puede tener fe en Rusia.

A su vez, Mandelstam, en medio de un paisaje poético de Moscú divisa en el propio Kremlin un grandioso campanario, "Iván el Grande" — de la misma familia de la campana "rey" y el cañón "rey".

Iván el Grande, el campanario pasado de edad, sigue ahí parado como un tonto desde hace siglos.

Debería ir al extranjero para terminar de estudiar.

Pero le da pena... ¿cómo?

\footnotetext{
${ }^{22}$ En realidad, la historia de ambos artefactos es más compleja, sobre todo en lo que se refiere a la campana. Los comentarios de Herzen son característicos de una posición ideológica que no profundiza en la explicación histórica.
} 
La riqueza evocativa de la imagen, con sus paralelos históricos implícitos, hace un guiño respecto de la generación de Pedro I, quien por primera vez mandó a la juventud noble a hacer sus estudios en Europa; y otro, respecto del concepto de "pasado de edad" referido a un "adolescente". En una comedia dieciochesca de Fonvizin, El Adolescente, se hace una ácida parodia de la ignorancia y brutalidad de los jóvenes nobles sin estudios ni pulimiento. Mandelstam señala una minoría de edad alegórica como estado permanente de la cultura rusa. De hecho, el poeta ha conocido de cerca a una generación de "pasados de edad" posrevolucionarios: desde los años veinte el régimen soviético destruyó, expulsó o encarceló a la crema y nata de los especialistas y técnicos del viejo régimen; ahora está preocupado en preparar a sus propios cuadros y sufre el mismo problema de falta de "recursos humanos" que se vivió en el siglo XVIII: ¡enorme avance histórico!

Es en este terreno donde virtualmente cruzan las espadas los occidentalistas y los eslavófilos. Sin pretender definir a Tarkovski como un representante de la eslavofilia mesiánica, seguiré esta línea de pensamiento, observando su desarrollo desde Andrei Rubliov hasta Nostalgia. En cuanto a este tema, el último tópico de Andrei Rubliov que abordaré aquí es el de la "tercera Roma".

Moscú es la "tercera Roma”. Se trata de una antigua idea teológico-política que viene del siglo xv: Roma es pilar de la cristiandad primera; Constantinopla, la segunda Roma, da origen a la variante ortodoxa del cristianismo — que desde su propia óptica es la única verdadera; después de su caída bajo el embate del Islam en el siglo Xv, el papel de la tercera Roma le habría tocado a Moscú. Esta idea renace en especial durante la polémica intelectual entre eslavófilos y occidentalistas y en el pensamiento literario de Dostoievski. El mesianismo inherente a la idea de la tercera Roma podría tal vez fungir como analogía del marxismo. En torno a la tercera Roma giran las ambiciones históricas 
de los religiosos rusos en la película. Estas ambiciones se oponen a una realidad que Tarkovski enfatiza, una realidad nada imperial, de miserias morales y materiales en las que el individuo se pierde, sin ser tomado en cuenta, y sin embargo sobrevive: cae, se hunde, se levanta, sigue adelante, crea... ¿En qué condiciones? Justamente en condiciones de supervivencia. La idea mesiánica entra en contrapunto con la muestra del viacrucis del artista, quien es más testigo que participante de los acontecimientos y sin embargo se involucra en todo, se percibe como perteneciente a todo y se siente culpable de todo. Este es el caso de Dostoievski, con su culpa universal pero también con su afán redentor del "pueblo" y de la fe; y de Ajmátova: “¿Cómo pudo haber sucedido/ que culpable de todo sea yo?", dice en el Poema sin héroe. Aparentemente la fe es el elemento que Tarkovski rescata (cfr. supra los versos citados de Tiutchev). El milagro del arte surge bajo el influjo de la esperanza y de la fe en el pueblo. Las bellísimas imágenes finales: la Trinidad, los caballos, la lluvia, el río, ofrecen una conclusión entusiasta a una paráfrasis de la realidad sórdida e irresoluble. La "tercera Roma" se disuelve en el milagro del arte y de una espiritualidad laica, simbolizada sin embargo por la religión, la cual dentro de la ideología eslavófila es a la vez atributo del carácter nacional y lección potencial que dar al mundo.

El mismo hilo se retoma desde otro ángulo en El espejo. El tema del despertar de la conciencia ética se aborda aquí desde una experiencia individual y aparentemente autónoma. Sin embargo, ya describí cómo funciona el mecanismo del sentido puesto en marcha como imagen de la palabra que brota pese a los impedimentos incluso físicos o morales. ${ }^{23} \mathrm{El}$ héroe, que en

\footnotetext{
${ }^{23}$ He aquí el comentario del propio Tarkovski: "es la película en su totalidad la que se podría decir que lleva en sí, en sentido estricto, una versión ideológica de la realidad. Una palabra, por su parte, es en sí una idea, un concepto, en cierta medida una abstracción. Una palabra no puede ser un simple sonido" (Tarkovski, Esculpir el tiempo, p. 178).
} 
la película es sólo Voz y mirada, está a punto de morir por no resolver sus conflictos con la gente que más quiere: la Madre, el recuerdo del Padre, la Esposa, los Hijos. La Voz describe escrupulosamente y el ojo de la cámara registra con celo el despertar de esta conciencia desde las etapas más tempranas. Los recuerdos de la Madre se superponen, formando un todo con la conciencia del protagonista, al remontarse a la etapa prenatal, incluso desde la concepción. El universalismo de los conceptos y la originalidad personalista de las imágenes (sabemos que Tarkovski reconstruyó la casa de su infancia para filmarla), así como el elemento de la Historia, el poder omniabarcador de la música y la presencia de la poesía, evitan que la película caiga en lo obvio y lo simple. Las inserciones documentales agregan a esta trayectoria estrictamente personal un fondo histórico que da pauta a todos los episodios: la gran represión, con sus implicaciones siniestras, la Segunda Guerra Mundial, la bomba atómica sobre Hiroshima, la guerra civil española, la revolución cultural china...

Conque, es ahora cuando se nos ocurrió nacer.

Aquí, al calcular con precisión el tiempo, por no dejar pasar ninguna visión insólita, nos hemos desprendido del no ser. ${ }^{24}$

Las conversaciones aparentemente casuales cobran un sentido distinto confrontadas a estas inserciones documentales. Al mismo tiempo logran un simbolismo más allá de la historia particular si se aprecian desde el todo, como señalé antes respecto del "epígrafe" (el consultorio de la logoterapeuta).

En el primer episodio la Madre mira el camino y tiene una conversación con un doctor desconocido; aparte de su contenido humorístico, se sugiere un deterioro en la relación entre los

\footnotetext{
${ }^{24}$ Ajmátova, Primera elegía boreal (la traducción es mía). La cita no está incluida en el texto de El espejo pero ilustra bien la idea.
} 
Padres y se incluye una reflexión aparentemente gratuita acerca de la condición estable de las plantas en comparación con la movilidad e inquieta vanidad de los seres humanos. Cuando la cerca se rompe bajo el peso de los personajes, la Madre y el doctor caen sobre las raíces de un árbol. El tema de la permanencia de las raíces frente a la tragedia del desarraigo se retoma en un episodio posterior.

Este episodio hace contrapunto con otro aparentemente inconexo, el de los españoles; este último trata de los hijos de unos refugiados republicanos en la Unión Soviética, de una mujer española que se casó con un ruso e hizo familia allí y de uno de los llamados "niños de España" del 1939, quien pudo visitar su patria y cuyos recuerdos de la despedida de sus padres vienen acompañados de inserciones documentales sobre la guerra civil y la partida de los niños emigrantes. Los temas tratados en este episodio: las raíces rotas, los afectos extraviados, las evocaciones de una corrida de toros y del baile flamenco en un contexto tan ajeno e inorgánico como lo es un apartamento moscovita de los años sesenta, con un paisaje invernal de fondo - que desentona sin duda con el ritmo cálido de la guitarra española- inscriben el leitmotiv de la película - el regreso a la infancia - en un conjunto coherente de reflexión sobre lo ruso, reiterando temas como la identidad, la pertenencia, las raíces perdidas, los destinos torcidos por un transplante forzoso o por no haberse mantenido fiel a la tierra, como es el caso del protagonista dueño de la Voz.

La Trinidad del Antiguo Testamento de Rubliov, imagen emblemática de la identidad rusa en la época de Tarkovski, reaparece en El espejo en una reproducción colgada en el apartamento del protagonista.

La secuencia descrita forma un todo con un episodio que resulta ilegible fuera del hilo conductor que estoy tratando de mostrar. Se trata de un corte temporal onírico: el hijo del protagonista, el muchacho Ignat, se encuentra de pronto en el 
mismo apartamento de su padre, pero como si retornara a la infancia de éste. Todo sucede aparentemente durante la guerra. Unas vecinas, que vienen de otra época, le hacen leer un fragmento de la carta de Pushkin a Chaadáiev sobre los destinos históricos de Rusia. Luego los personajes fantasmales desaparecen, y sólo una mancha de vapor dejada por una taza de té sobre la mesa, una mancha que lentamente desaparece - como una vida que se extingue-, viene a ser la prueba de su presencia. La Madre (que de hecho es la abuela de Ignat) toca a la puerta, el niño abre pero no la reconoce, y ella misma dice que se equivocó de puerta (¿o de época?) Hay aquí otro motivo poético implícito (v. Pasternak, Okudzava, Ajmátova). ${ }^{25}$

¿Qué relación puede tener este episodio, esta carta, con el conjunto de la película? Se trata del tema de la continuidad generacional de las ideas y de las identidades históricas.

P. Chaadáiev (1794-1856) ha sido siempre una figura polémica en la cultura rusa. Fue crítico del régimen zarista y su importancia ha sido recuperada por la historia literaria rusa como característica del ambiente intelectual del período de Pushkin. No obstante, sus Cartas filosóficas ${ }^{26}$ (1836), donde expresa abiertamente sus opiniones, se conocen sólo gracias a la polémica con Pushkin acerca de los destinos históricos de Rusia.

Chaadáiev señala con amargura el retraso político y cultural de Rusia, y su aparente falta de contribución al patrimonio cultural de la humanidad, adjudicándolos en particular a las características histórico-geográficas de Rusia, pero sobre todo a la cerrazón de la mentalidad nacional que, junto al cronotopo

${ }^{25}$ Ajmátova dice en "El entierro de una época": "El hijo negará a la madre,/ el nieto, angustiado se irá" (poema del ciclo "El año cuarenta").

${ }^{26}$ La primera de ellas fue publicada en 1836, pero se conocía desde 1829 en manuscrito (como las demás). Su publicación provocó un escándalo con tintes políticos; la revista que la publicó (Telescop) fue cerrada mientras Chaadáiev era declarado demente y puesto bajo arresto domiciliario, bajo vigilancia médica, durante un año. 
fatal (una Historia subsidiaria de una Geografía poco feliz), se debe a la adopción de la variante ortodoxa del cristianismo. ${ }^{27}$ Su visión del presente y del futuro de Rusia es extremadamente pesimista. Pushkin en cambio, en su carta a Chaadáiev pondera el importante papel histórico de Rusia como barrera entre la cultura occidental y el empuje de las hordas mongoles durante la Edad Media, ${ }^{28}$ y defiende el futuro de los destinos nacionales de una manera patriótica y esperanzada.

La lectura de la carta de Pushkin cobra sentido si confrontamos, otra vez, a Tarkovski con Mandelstam. Significativamente, la posición de Chaadáiev carece de lugar en el episodio mencionado, mientras que está presente sólo la respuesta de Pushkin. ${ }^{29}$ Por otro lado, si la lectura se realiza desde el conjunto de las tres películas que estamos examinando, cabe decir que la otra gran ausencia es la de Mandelstam.

Consideremos además que a Chaadáiev se le lee también a través de Mandelstam, quien recupera la obra de aquél en un

\footnotetext{
${ }^{27}$ Chaadáiev señala en particular que si en Europa Occidental el cristianismo contribuyó a la abolición de la esclavitud y del servilismo, en Rusia, en cambio, el servilismo entra en escena varios siglos después (s. XVII) de la adopción del cristianismo (s. IX), supuestamente como consecuencia del influjo anti-civilizador de la ortodoxia griega.
}

28 La presencia de este motivo es evidente en Andrei Rubliov, aunque Tarkovski, aparte del uso metafórico del tema del "yugo tártaro-mongol", no enfoca el tema tan unidireccionalmente como lo hace la historiografía oficial (tanto la rusa como la soviética), al mostrar la cooperación de los mismos príncipes feudales con los invasores, es decir, contra su mismo pueblo. Por el contrario, en $E l$ espejo, los episodios documentales de la revolución cultural china y de los conflictos en la frontera que tuvo la URSS con China forman un todo con la lectura de la carta de Pushkin sobre la Rusia defensora de Europa contra las hordas mongoles.

${ }^{29}$ M. M. Bajtín ofrece interesantes indicaciones acerca de la emergencia del sentido de un enunciado mediante el concepto de entimema, una de sus metáforas epistemológicas. Como es sabido, entimema es un silogismo con una de las premisas calladas o implícitas, dadas por hecho. En el episodio mencionado de $E l$ espejo estamos justamente ante este caso. La carta filosófica de Chaadáiev es el elemento sobreentendido de este entimema (cfr. V. Voloshinov/M. Bajtín, "La palabra en la vida y la palabra en la poesía", en Mijaíl M. Bajtín, Hacia una filosofía del acto ético y otros escritos, p. 115). 
contexto intensamente crítico y contemporáneo, un momento en que el destino de Rusia parecía tomar un nuevo rumbo (1914). ${ }^{30}$ Dice Mandelstam: "Chaadáiev fue el primer ruso que en verdad, esto es, ideológicamente, visitó Occidente pero encontró el camino de regreso. Sus contemporáneos lo sentían instintivamente y valoraban tremendamente la presencia de Chaadáiev". (Mandelstam, vol. 2, p. 156). La postura crítica y occidentalista de Chaadáiev en las Cartas filosóficas, aunque amarga, era profundamente patriótica y no fue entendida en su justa dimensión histórica en su propio tiempo. Ochenta años después, Mandelstam afirmará que el "pensamiento de Chaadáiev, que es nacionalista en sus orígenes, lo sigue siendo también cuando confluye con Roma". Para Chaadáiev, Roma representa la unidad y cohesión histórica de la cultura europea, de las que Rusia está excluida. Para Mandelstam, Roma es cifra poética de la verdad universal:

Sólo un ruso pudo descubrir un Occidente que resultara más condensado y concreto que el propio Occidente histórico. Justamente por el derecho de ser ruso, Chaadáiev ingresó al terreno sagrado de la tradición con la cual no se relacionaba por medio de una continuidad. Al terreno donde todo es necesariedad, donde cada piedra, cubierta por una pátina del tiempo, duerme sellada en una bóveda, Chaadáiev aportó la libertad de la conciencia moral, ${ }^{31}$ el don de la tierra rusa, la mejor flor por ella cultivada. Esta libertad equivale a la grandeza congelada en las formas arquitectónicas, por su importancia es igual a todo aquello que Occidente creó en el aspecto de la cultura material (Mandelstam, vol. 2, p. 155).

${ }^{30}$ En 1913-1914 el filólogo M. O. Gershenzon edita la obra de Chaadáiev, que apenas en aquel momento puede apreciarse en su totalidad (cfr. Sochinenia $i$ pis'ma, 2 vols., Moscú; reproducción xerográfica, Ann Arbor, 1975).

${ }^{31}$ En Mandelstam, nravstvennaia svoboda (libertad moral, en sentido amplio) podría traducirse también como 'libre albedrío', pero la connotación exclusivamente religiosa y católica del término en español es inexistente en el artículo sobre Chaadáiev. 
Las opiniones de Mandelstam permean como un gran sobreentendido, directamente o a contrapelo, el discurrir filosófico-cinematográfico de Tarkovski en muchas de sus vueltas. Tarkovski conserva la contrarréplica de Pushkin y omite la apreciación de Mandelstam sobre Chaadáiev, así como las propias palabras de Chaadáiev (que son el complemento indispensable para entender el alcance de la respuesta pushkiniana), porque lo que le importa es señalar la continuidad de la tradición rusófila al mostrar la transposición de la identidad del Padre al Hijo (el protagonista), y de allí al Nieto (Ignat), que es quien escucha, significativamente, la citación de la carta de Pushkin. ${ }^{32}$

Otras estrofas de Arseni Tarkovski acompañan toda esta compleja secuencia (Ignat en la casa del Padre - el corte temporal (la carta de Pushkin); los españoles (inserciones sobre la guerra civil); las memorias del padre sobre la guerra (el instructor militar y episodios documentales del Perekop); la posguerra y el presente (la bomba de Hiroshima, la revolución cultural china).

De esta manera, la trayectoria individual y el viaje interior hacia el origen se inscriben no sólo en la historia sino también en el debate ideológico acerca de la identidad rusa, cuya búsqueda y/o definición es en gran medida el aliento de la obra de Tarkovski. No pretendo reducir la riqueza de sus creaciones a sólo este aspecto. También estoy consciente de que es imposible transcribir la compleja semiología cinematográfica en un metalenguaje unitario y carente de la profundidad, simultanei-

\footnotetext{
${ }^{32}$ Con los años Chaadáiev cambió su postura rígida acerca del destino histórico de Rusia e incluso llegó a anticipar ciertas ideas eslavófilas al respecto. No obstante, siempre se deslindó del extremismo religioso y nacionalista de los eslavófilos y rechazó su "utopía retrospectiva" por cuanto implicaba "una arrogante apoteosis del pueblo ruso", que según Chaadáiev distorsionaba la imagen de "la humildad religiosa..., de la modestia del espíritu, que siempre han sido el rasgo distintivo de nuestro carácter nacional", como escribe en una carta a Schelling.
} 
dad y vivencialidad de la imagen filmada, la cual permite la convivencia del suceso narrativo, el recuerdo y el comentario poético y/o musical. Pero en cualquier caso la palabra, la expresión verbal, es aun más universal que cualquier otro derivado discursivo, por complejo que fuese. Me parece importante inscribir la obra de Tarkovski en un debate histórico, mostrar su carácter abierto e inconcluso, lo cual justamente garantiza su supervivencia y la posibilidad de lecturas múltiples.

Siguiendo con la idea de la poesía cinematográfica de Tarkovski y de su profunda y no confesada deuda con Mandelstam, recordaré en qué forma este poeta plantea el carácter dialógico de la poesía en su breve escrito "Sobre el interlocutor" (1913), donde por cierto define la poesía como la conciencia de tener razón.

El interlocutor es un elemento indispensable de la poesía porque implica una atención y una respuesta sin la cual la creación está muerta. Para un ser humano, dice Mandelstam, no hay nada más terrible que otra persona absolutamente indiferente a su existencia. No obstante, el interlocutor de este diálogo tan específico como lírica es de una índole muy particular. Para Mandelstam, la poesía es un mensaje embotellado que se echa al azar y se abandona a las inclemencias del océano de la vida. Quien encuentre la botella y lea el mensaje es su destinatario. Para este propósito cita el conocidísimo poema de E. A. Boratynski (1800-1844; también integrante indispensable del ideario de la época de Tarkovski) dirigido al lector potencial del futuro, que puede servir de comentario o de motivo en torno a ese espectador participativo, creador de un sentido para la obra, que aparece en las reflexiones teóricas del cineasta:

Mi don es pobre, y mi voz no es muy sonora, pero vivo, y mi huella en la tierra a alguien le agrada: 
la hallará mi lejano descendiente

en mis poemas; con suerte, mi alma

entrará en comunión con la de él,

y como en la mía he hallado un amigo,

así en las generaciones por venir

encontraré un lector.

El poeta sólo tiene que ver con un interlocutor "providencial". Si bien algunos poemas pueden estar dirigidos en forma de epístolas o dedicatorias a personas concretas, "la poesía como una totalidad siempre está dirigida a un destinatario más o menos remoto y desconocido, de cuya existencia el poeta no puede dudar sin dudar de sí mismo" (Mandelstam, vol. 2, p. 150). He aquí una prefiguración del diálogo en el "gran tiempo" que describe Bajtín: "No hay nada absolutamente muerto. Cada sentido encontrará su fiesta de resurrección" (Estética de la creación verbal, p. 373).

Los teóricos del cine, a su vez, hablan de la posibilidad de una obra abierta que exige un lector/espectador participativo. Sin entrar en discusiones acerca de si la obra de Tarkovski responde o no a las definiciones de esta clase de cine, recordaré que el mismo realizador sí incluyó al destinatario participativo e interesado en la concepción de su propia cinematografía. Dice Tarkovski: "El mayor estímulo para mi trabajo es que haya espectadores para quienes sea importante el hecho de entablar un diálogo precisamente conmigo [...] El no intentar desarrollar la capacidad crítica del público frente a nuestros propios juicios equivale a tratarlo con una indiferencia total" (Tarkovski, Esculpir el tiempo, p. 175). La posibilidad de ver la obra de Tarkovski como abierta es la garantía, aunque hasta ahora no asegurada, de que sus obras sobrevivan para el espectador futuro. Por otra parte, su vida y obra resultan emblemáticas y autorreferenciales en cuanto a su concepción del arte y del 
sentido de la vida como misión, haciendo eco a las concepciones filosóficas de otro dueño de los pensamientos de la generación, M. Bajtín. ${ }^{33}$

El hilo de la identidad, de la autobiografía intrínseca y de la autoafirmación mediante la creación se entreteje en el pensamiento del cineasta con ciertas posturas ideológicas afines a sus contemporáneos, quienes retomaban a su vez la estafeta de las tendencias de la cultura rusa - abandonadas o semiolvidadas durante el período soviético- del siglo XIX y anteriores. Así, en la obra de Tarkovsky aparece de una u otra forma un cierto mesianismo inherente a la convicción en la originalidad absoluta de los destinos históricos de Rusia, junto con las definiciones rotundas del carácter nacional. Aunque se trate de una marca generacional, no deja de estar profundamente personalizada y sus implicaciones jamás se manifiestan de una manera unidireccional y reductora, sino que permiten lecturas ambivalentes y polisémicas. No obstante, como representante de una generación, Tarkovski contribuyó con su palabra a un diálogo en el "gran tiempo", y es interesante ponerla de relieve en una situación que prevalece quince años después de su muerte.

Nostalgia es la primera obra de Tarkovski realizada en su semivoluntario exilio europeo, en medio de un reconocimiento mundial y bajo el veto oficial en su país de origen. El título habla por sí mismo: en él aparece condensado el rechazo a su circunstancia presente, aún más intenso que aquel que implicaba la situación descrita en Andrei Rubliov.

En Esculpir el tiempo, Tarkovski señala explícitamente que la intención de Nostalgia fue mostrar la imposibilidad para un

\footnotetext{
33 "El sentido no nace y no muere; la serie semántica de la vida, esto es, la tensión cognoscitiva y ética de la vida desde su mismo interior no puede ser iniciada ni concluida. La muerte no puede ser la conclusión de esta serie de sentidos, es decir, no contribuye a una vida que desaparece como conclusión positiva" (Estética de la creación verbal, p. 315). En cambio, una obra de arte sí logra esta conclusión positiva, conclusión estética de una vida y una obra.
} 
ruso de vivir en el extranjero, debido a determinados rasgos del carácter nacional. Pero junto a esta tendencia autobiográfica - en esta época Tarkovski vive exactamente el proceso que está filmando-, hay en la película el tema del "tiempo descoyuntado"34 con el que es imposible relacionarse, aunque tampoco se le puede componer, porque se ha pasado el momento de salvar al mundo. Sin duda, Tarkovski pertenecía en muchos sentidos a los "apocalípticos" caracterizados por Umberto Eco: su actitud hacia la cultura es elitista y esencialista, su actitud hacia la realidad es escatológica: "La estructura psíquica de un artista predispone a una catástrofe... La cultura poética surge del deseo de prevenir la catástrofe, ponerla en dependencia del sol central de todo el sistema, trátese del amor del que habló Dante, o de la música, a la que al final de cuentas llegó Blok" (Tarkovski, Esculpir el tiempo, p. 40).

Otra vez se trata de un creador, en esta ocasión ya directamente de un poeta, que busca en Italia la huella de un compositor ruso del siglo XVIII, para escribir sobre él un libro. Aquel siervo por nacimiento, gracias a su talento es enviado a perfeccionar su don en Italia, y pese a que permanecer en el extranjero no sólo le hubiera garantizado una libertad personal, sino un cierto reconocimiento como artista, regresa a Rusia a su condición servil, donde poco después se suicida.

El personaje Gorchakov ${ }^{35}$ no es un exiliado político ni se halla en conflicto abierto con el régimen; simplemente realiza un viaje de investigación, protegido por las instancias oficiales de su propio país y del país anfitrión. De principio a fin de la película, la característica principal de Gorchakov es negar rotundamente cuanto le rodea: el paisaje italiano con sus anti-

\footnotetext{
${ }^{34}$ Evidentemente remite al "the time is out of joint", de Hamlet.

35 Gorchakov es sin duda una especie de alter ego de Tarkovski, cosa que él confiesa en Esculpir el tiempo. Por supuesto, hay que tomar con reservas esta identificación: Tarkovski encuentra en la creación una salida a su conflicto, mientras que su héroe perece simbólicamente como una promesa incumplida.
} 
güedades culturales, el afecto y la ayuda de quienes están cerca, la belleza femenina e inclusive sus propios objetivos. Cruza media Italia para visitar a la Madonna del Parto de Piero della Francesca, imagen que aparentemente le recuerda a su mujer, pero se niega a bajar del auto para verla: "Está harto". Lo que tiene en mente, más allá de lo que percibe a su alrededor, es su casa de campo en Rusia como símbolo de su inadaptación. Aparece aquí nuevamente el motivo inicial de El espejo: la casa de la infancia, las raíces donde empieza y termina todo.

Italia, patrimonio universal de la humanidad, tiene un lugar particular en la obra de Tarkovski: en Andrei Rubliov, la condición servil del creador de la campana está implícitamente cuestionada a través de la mirada de los embajadores italianos. La propia arquitectura del Kremlin, como Tarkovski sabe, testimonia la intervención de los arquitectos italianos. En El espejo, el protagonista tiene contacto de niño con el arte italiano (el libro sobre Leonardo, que leerá después su hijo). La música de la película (por ejemplo, la de Pergolesi) pertenece a la experiencia íntima y personal de Tarkovski. Esta universalidad del legado de Italia es inherente a la misma cultura rusa. Es una instancia propia y a la vez ajena. Su "otredad" queda doblemente enfatizada: en tanto influencia "ajena”, pero también en tanto símbolo de degradación de toda la cultura contemporánea.

En efecto, para el protagonista de la película, el país que visita representa el estado de descomposición de la cultura y lo extranjero como circunstancia difícilmente digerible. "Italia pasa a formar parte de la conciencia de Gorchakov, explica Tarkovski, en un momento en que éste ha roto con la realidad (no solamente con las condiciones de la existencia, sino con la existencia misma, la cual nunca satisface las aspiraciones existenciales del individuo) y se le muestra a través de esas magníficas ruinas que parecen surgir de la nada. Estos fragmentos de 
la civilización a la vez universal y extraña son una especie de epitafio a la futilidad del esfuerzo humano, una señal de que la humanidad ha tomado un camino que únicamente puede llevarla a la destrucción" (Tarkovski, Esculpir el tiempo, p. 202). La oposición entre la decadencia del opulento y desencaminado Occidente y la ascética espiritualidad rusa, exenta de gozo por la vida y de erotismo - al que se considera siempre como un pecado-, la tendencia a erigir la pobreza y la insuficiencia como un valor universal (un valor cristiano), así como la negación a dialogar y a interactuar con el prójimo restan, a mi modo de ver, validez a la crítica de la civilización universal que emprende Tarkovski en esta película. ${ }^{36}$

El contacto con lo ajeno lleva a Gorchakov a encerrarse cada vez más en sí mismo. Sólo el contacto con Domenico, un loco empeñado en salvar al mundo, atrae su interés, aunque no lo bastante para tomar en serio su manía escatológica. Domenico es una de las variantes de la figura del "loco sabio", holy fool (en ruso yurodivy), figura presente de diferentes maneras en las tres películas, y en todas ellas problematizada. El yurodivy es un personaje característico de la religiosidad ortodoxa; es un santo demente al que se le permiten ciertas libertades debido a su don profético y su posición extraoficial. En Andrei Rubliov, tenemos a la Loca, que no profiere palabra, y a la que Rubliov protege y mantiene como una especie de ejemplo evangélico de los "pobres de espíritu”. Significativamente, es interpretada por la misma actriz que aparece en el episodio de

36 "El arte moderno ha equivocado su ruta al abandonar la búsqueda del significado de la existencia, por la afirmación de la individualidad en sí misma, y adquiere un aire sospechoso cuando lo que debería ser acto creativo es la proclamación del valor intrínseco del acto personal. Pero la individualidad no se afirma a través de la creación artística, ya que sirve a una idea más alta y comunitaria. El artista es siempre un servidor perpetuamente en deuda por el don que le fue dado como un milagro. El hombre moderno, sin embargo, no quiere hacer ningún sacrificio, aun cuando la verdadera afirmación del 'yo' sólo puede ser expresada a través del sacrificio" (Tarkovski, Esculpir el tiempo, p. 41). 
la fiesta pagana, donde representa una sensualidad sin límites. En El espejo, la Madre es comparada con un personaje análogo en Dostoievski — la loca Maria Timofeevna de Los demonios - episodio que le da un determinado fondo a la figura de la Madre, pero también complementa el ambiente descrito en la editorial e imprenta del Estado. (En Stalker, veremos al personaje central en el papel, ya plenamente desarrollado, de holy fool). El marginal Domenico no tiene un público adecuado para oír sus profecías, pero tampoco posee un discurso coherente como para que le presten atención. Por eso, su acto sacrificial de autoincineración sólo es presenciado por seres tan segregados y dementes como él. El acto ritual mágico encaminado al mismo propósito que el sacrificio queda también truncado porque Gorchakov llega tarde para completarlo: la fuente termal que debe atravesar con una vela encendida en la mano está vacía, y sólo queda basura en el fondo.

La línea de la salvación del mundo mantiene el estatus de la premisa callada del entimema escatológico. Uno de los motivos que la hace emerger es el del consumismo, ilustrado por el tópico de la ropa y los zapatos. A Gorchakov, que anda siempre mal vestido, le molesta la abundancia de los finos zapatos italianos. En efecto, todo esto pertenece al orden de lo superfluo, pero no puede analizarse separado de otros elementos más importantes, que muestran también la degradación espiritual del hombre moderno. La prédica moral y la enseñanza ética parecen carecer de argumentos: Gorchakov calla y no responde, toda su figura niega cualquier interacción. Por su parte, Domenico es un demente rebasado por la magnitud de la tarea que se había autoimpuesto. En Nostalgia, la posición de Tarkovski en torno a la exclusividad del espíritu ruso está llevada a sus últimas consecuencias: la incomprensión, la incomunicación y la muerte son la consecuencia de esta falta de respuesta en el diálogo.

El consumismo propio de la cultura contemporánea es particularmente criticado a través de la figura femenina. La posi- 
ción de Tarkovski respecto de la mujer, si la remitimos al contexto amplio y simbólico de la película, y más allá del personaje de Eugenia, se reduce a lugares comunes que no se cuestionan, sobre todo religiosos; no se pregunta ni se analiza, se sabe todo de antemano; estamos ante un rechazo rotundo basado en las premisas judeocristianas: la mujer debe ser madre y sacrificarse por los hijos, éste es su destino. Por contraste, los intereses intelectuales femeninos se muestran ligados a su sexualidad; su frivolidad aparece simbolizada en su elegante atuendo y en sus incómodos y humillantes zapatos de tacón alto. El carácter hedonista de la civilización actual, que nada recuerda y todo lo devora sin reflexión, está metaforizado así en Eugenia, dedicada a las superficialidades e incapaz de defender su propia consistencia (sobre todo porque no se le escucha). Ella escoge su destino de acuerdo con lo que su hombre en turno le exige, de modo que le resulta igual estar en Moscú, en Italia o en la India, siempre y cuando sea con una pareja. ${ }^{37}$

La espiritualidad aquí coincide con la religión, particularmente con la de los "pobres de espíritu". Los débiles intentos de Eugenia por autoafirmarse como sujeto se cancelan tanto por su propia inautenticidad, como por la falta de respuesta a sus preguntas.

Los poemas de Arseni Tarkovski —uno leído en ruso, otro en italiano-, a pesar de su carácter fúnebre y por el efecto de combinar las dos lenguas, suplen hasta cierto punto la permanente frustración del diálogo que la película muestra. Porque si bien se encuentra condenada desde un principio, Eugenia pide a Gorchakov que le hable, que le explique, y no obtiene respuesta; el diálogo truncado con Domenico no lleva a ningu-

\footnotetext{
${ }^{37}$ En este punto, lo particular de la historia concreta - justificable en sí misma-, entra en conflicto con la intención universalista y generalizadora de la película, haciendo que el tema de la mujer resulte equiparable al tratamiento de Tolstoi (como un ideal positivo: maternidad, familia, sacrificio), y que caiga en una intolerancia anticuada y pseudorracional digna de un Otto Weininger (Sexo y carácter, 1903), cuando en el fondo se trata de juicios morales, disfrazados de naturales.
} 
na parte y el personaje, como un "loco santo", se sacrifica en vano; la muerte de Gorchakov, por su parte, queda inatendida. De la misma manera, el símbolo de la "tercera Roma" se ha reducido a las dimensiones de una casita de campo, agazapada al pie de una catedral católica en ruinas, sombra de una grandiosidad pasada.

Hablar de la conciencia moral o de la primacía de los valores espirituales sobre los materiales resulta frustrante y poco prometedor desde la miseria de las condiciones propias. Habiendo dejado una espléndida obra que en cierta forma plasma en imágenes visuales el debate ideológico en que la cultura rusa permanece inmersa desde hace más de tres siglos, Tarkovski pierde el round en la presente involución del "gran tiempo". En cuanto profeta del sacrificio, por lo pronto no ha sido oído. No le tocó ser testigo de la gran dispersión de Rusia comenzada justo después de su muerte. Como última huella y legado en el mundo dejó precisamente el Sacrificio, su "última palabra", película un tanto profética a la luz de los acontecimientos de Chernóbyl que marcaron el inicio de la perestroika, proceso que llevó a la destrucción del mundo en que Tarkovski se orientaba con su juicio ético y estético. Rusia se ve ante el reto de abandonar su espíritu mesiánico y establecer vínculos más orgánicos con la cultura universal. El proyecto disidente, que apostaba a una espiritualidad inherente al carácter nacional ruso queda frustrado, al menos por el momento. ${ }^{38}$

\footnotetext{
38 Para mostrar que el mesianismo apocalíptico no está muerto, cito a un artista, Yuri Seliverstov (1940-1990), perteneciente a la generación que sigue a la de Tarkovski: "Sócrates en el juicio dijo sus últimas palabras: ya es tiempo de que los abandone, me toca morir, a vosotros vivir, pero ¿qué cosa es mejor?, nadie lo sabe salvo Dios... Pero los rusos son Sócrates cien veces... Somos más que escatológicos. El destino del mundo se observa a través del destino de Rusia. El cisma, la ruptura, la dispersión de Rusia es el fin del mundo, aunque a los propios rusos no les importe nada. Es incluso mejor que mueran sin darse cuenta de que con su propio fin llega el fin del mundo, y que su rusa Bizca [la Muerte], con la guadaña, es la guardiana del mundo" (Texto publicado en Internet: http:// portland.shef.ac.uk./bakhtin/sec/sec02681.html).
} 
La sensación ambivalente, tanto de admiración y orgullo como de contrariedad y desacuerdo en torno al cine de Tarkovski es un resultado sin duda previsto por el propio realizador: "Una verdadera imagen artística da al espectador una experiencia simultánea de los más complejos y contradictorios —algunas veces mutuamente excluyentes - sentimientos" (Tarkovski, Esculpir el tiempo, p. 111).

Tarkovski, hombre "feliz", no murió en su cama ni en su casa; casi como última víctima de un régimen moribundo, murió en el extranjero, excomulgado de su medio natural y privado de su interlocutor más directo. Pero el interlocutor de Tarkovski en cuanto poeta encuentra su mensaje dentro de la botella lanzada al azar, al océano: el mensaje está destinado al "gran tiempo".

Como divisa de su vida podríamos recordar las siguientes líneas escritas por su padre:

Para que no se venga abajo, habitad la casa.

Convocaré cualquiera de los siglos

y entraré para fundar mi casa en él.

Por eso vuestros hijos y mujeres

están sentados en una misma mesa,

que es la misma para el nieto y el bisabuelo:

el futuro se genera ahora mismo,

y si en este instante levanto mi mano,

los cinco rayos con vosotros se quedarán...

Para que mi sangre fluya de siglo en siglo

me basta mi propia inmortalidad.

Por el calor de un hogar seguro

yo pagaría con gusto con mi vida,

si su aguja voladora no me llevara

cual hilo por el mundo. ${ }^{39}$

39 Arseni Tarkovski, "Vida, vida” (Traducción mía). 
Como director de cine, Tarkovski obviamente tenía que partir de las reglas y las prácticas que se aprenden en el oficio y del bagaje específico de la experiencia del cine mundial. Pero en cuanto creador, Tarkovski parte de un propósito explícito de rebasar los tecnicismos, los pragmatismos, la erudición y la búsqueda de los efectos inmediatos de su trabajo sobre el entorno, tales como el reconocimiento, la fama o el dinero. No es que todos los factores mencionados tuviesen por fuerza que estar ausentes de su horizonte existencial; nadie puede excluir lo cotidiano de su vida sin caer en el quijotismo y/o la demencia. Pero trabajó siempre como alguien que tenía algo importante que comunicar a la gente, mediante los recursos específicos del arte cinematográfico, que él reinterpretó y reevaluó en su obra de una manera radical y sin concesiones. Así, los elementos éticos de su "mensaje", en su vínculo indivisible con los efectos estéticos que su obra produce, deben tomarse en cuenta al tratar de entenderla. Porque ésta era su propuesta y su intención, y en este sentido su trayectoria se inscribe de un modo peculiar en la tradición rusa de adoctrinamiento espiritual desarrollada por el arte ruso sobre todo en el siglo XIX, pero que, de acuerdo con los conocedores, se remonta a una tradición filosófica mucho más remota.

\section{Bibliografía}

Bajtín, M. M., Estética de la creación verbal [1979], Siglo XXI, México, 1980.

—, Hacia una filosofía del acto ético y otros escritos, Anthropos, Barcelona, 1997.

Bubnova, Tatiana, Contrapunto a cuatro voces en los caminos del aire. Pequeña antología de Anna Ajmátova, Osip Mandelstam, Borís Pasternak, Marina Tsvetáieva, UNAM, México, 1992.

Johnson, Vida T., y Graham Petrie, Andrei Tarkovski: A Visual Fugue, Indiana University Press, Bloomington e Indianapolis, 1994. 
Le Fanu, Mark, Andrei Tarkovsky, BFI Publishing, Londres, 1987.

Mandelstam, Osip, Obras [en ruso], 2 tomos, Judozhestvennaia Literatura, Moscú, 1990.

Malcuzynski, M.-Pierrette (ed.), Sociocríticas, prácticas textuales, cultura de fronteras, Rodopi, Amsterdam-Atlanta, 1991.

Señor, Carlos, Andrei Tarkovski, Ediciones JC, Madrid, 1994.

Tarkovski, Andrei, Collected Screenplays, trad. William Powell y Natasha Sinessios, Faber and Faber, N. Y., 1999.

Tarkovski, Andrei, Esculpir el tiempo [1986], UNAM, México, 1993.

Tarkovski, Arseni, Poemas de diversos años [en ruso], Sovremennik, Moscú, 1983.

Terras, Victor (ed.), Handbook of Russian Literature, Yale University Press, New Haven y Londres, 1985. 